\title{
European Contract Law(s) of What Colour?
}

\author{
Stefan Grundmann*
}

\begin{abstract}
European contract law has continuously developed over the last 25 years and it is a good moment to reflect on existing and future European contract law. The author argues that the current set of conflict rules provides for an equilibrium between party autonomy and necessary safeguards, but, in a future Code, these provisions can be designed more systematically. For substantive contract law, he argues that until 1999, EC Contract Law was mainly regulatory and not facilitative law. It focused on levelling out information asymmetries and was thus neither neo-liberal in approach nor heavily interventionist. With the Sales Directive of 1999, facilitative contract law also entered the scene. A fully fledged Code seems feasible now. It should be based on the acquis communautaire, should be optional (also in purely domestic cases), and modern, developing a design well beyond traditional Codes, dealing also with the host of new problems and solutions.
\end{abstract}

Resumé: Le droit européen des contrats a connu de façon continue pendant ces 25 dernières années, tous les cinq ans, des changements de plus en plus importants de style. C'est le moment opportun pour réfléchir sur le droit européen des contrats, existant et futur. L'auteur soutient que le présent ensemble de règles de conflit [c'est-à-dire dip] établit un équilibre entre l'autonomie des parties et leur nécessaire protection qui pourrait cependant, dans un futur Code, être préru de façon plus systématique. Pour le droit substantiel des contrats [c'est-à-dire : non pas dip], il soutient que jusqu'en 1999, le droit des contrats de l'Union européenne avait principalement vocation à réglementer en non pas à faciliter les contrats. Notamment, il ne contenait guère de règles supplétives. Il se concentrait sur le rééquilibrage des asymétries d'information et n'était [c'est vrai qu'il dit 'is'] ainsi ni néo-libéral ni véritablement interventionniste. Or, avec la directive sur la vente de 1999, le droit des contrats supplétif est entré en scène. Un Code complet semble à présent faisable: il devrait être basé sur l'acquis communautaire, être optionnel (également dans les cas purement de droit interne), et moderne, allant bien au-delà des Codes traditionnels, et permettant de recevoir tant de nouveaux problèmes que de nouvelles solutions.

Kurzfassung: Das Europäische Vertragsrecht hat sich über die letzten 25 Jabre stetig entwickelt, mit neuen Schüben und Stilwechseln etwa alle fünf Jahre. Zeit, sich zurückzulehnen und über Erreichtes und Kommendes nachzudenken. Im Vertragskollisionsrechts ist nach Meinung des Autors ein Gleichgewicht zwischen Wablfreibeit und Schutzinteressen grds. erreicht, das Design müsste jedoch in einem künftigen Europäischen Kodex ungleich systematischer und vollständiger werden. Im Sachrecht sieht er ein Regelwerk, das bis 1999 fast nur Regulierung umfasste, kaum die sog. Reservevertragsordnung, namentlich dispositives Recht. Ziel war und ist es hier vor allem, Informationsungleichgewichte auszugleichen, so dass dieses Regelwerk weder einem neo-liberalen laissez-faire verpflichtet ist noch besonders interventionistisch wirkt. Mit der Kaufrechts-Richtlinie von 1999, trat auch der andere, klassische Teil des Vertragsrechts auf die Europäische Bühne. Ein ausformuliertes

* Professor of Private Law, European Private and Private International Law at Humboldt-Universität, Berlin. 
Vertragsgesetzbuch erscheint jetzt denkbar: Es sollte auf dem acquis communautaire beruhen, wählbar sein (auch im Inlandsfall) und modern, d.h. im Zuschnitt einen erheblichen Schritt über die klassischen Codices hinaus tun und der Vielzabl jüngerer Probleme und Lösungen „ibren" Platz zuweisen.

\section{Introduction}

European Contract Law, in 2005, has several 'big birthdays'. Depending on which event is emphasised, it is now 25 or 20 years old (not considering labour law), and important new steps were taken again 15 to 10 years ago and five years ago. It is almost like a crescendo, every five years changing its rhythm and volume. Tewnty-five years ago, in 1980, the Rome Convention was ratified. Although it deals with conflict of laws, not substantive law, it still is the only 'European Act' to cover all contract law. ${ }^{1}$ And it remains one of the two points of reference for the key question of how much competition between contract laws is needed and possible. The year 1980 is prominent for a second reason. The international model which influences the process of Europeanisation of contract law most was ratified that year, that is, the UN Convention on the International Sale of Goods. ${ }^{2}$ It is a model in at least two respects: for the Sales Directive, the outstanding EC directive on contract law so far, and quite substantially also for all sets of principles developed up till now. ${ }^{3}$ Then, 20 years ago, in 1985/86, EC harmonisation of substantive con-

1 [Rome] Convention 80/934/EEC of 19 June 1980 on the law applicable to contractual obligations, OJ EC 1980 266/1, in force as of 1 April 1991, OJ EC 1991 C 52/1. Consolidated version (in force in all Member States) in OJ EC 1998 C 27/34. It is planned to integrate the content of the Convention into an EC regulation (Rome I) and thereby possibly also to change or introduce new core rules: see Green Paper on the conversion of the Rome Convention of 1980 on the law applicable to contractual obligations into a Community instrument and its modernisation, COM (2002) 654 final; ground breaking in this (and other) respect(s) G.-P. Callies, Coherence and Consistency in European Consumer Contract Law: A Progress Report, (2003) 4 German Law Journal 333; broad discussion in: S. Leible (ed), Das Grünbuch zum Internationalen Vertragsrecht (Munich: Selliers, 2004).

2 [Vienna] UN Convention on Contracts for the International Sale of Goods of 11 April 1980, United Nations, Official Records (1981) 178; for the states which have ratified the convention (altogether 67 in 3/2005) see www.uncitral.org/english/status/status-e.htm and annex B to (German) Bundesgesetzblatt 2003 II, 1330; see also J. Honnold, Documentary History of the Uniform Law of International Sales (Boston: Kluwer, 1989).

3 UNIDROIT (ed), Principles of International Commercial Contracts (Rome: Unidroit, 1994) (commercial contracts only); O. Lando / H. Beale (eds), Principles of European Contract Law, parts I (Dordrecht: Martinus Nijhoff, 1995) and II (The Hague: Kluwer Law International, 1999) and O. Lando / E. Clive / A. Prüm / R. Zimmermann (eds), 
tract law really started, with a series of directives, among them at least one 'core' directive, on consumer credit. ${ }^{4}$ Five years later, though one should consider an entire period really from 1990 to 1995 , the design of the two important directives of core contract law was established, that of the Standard Contract Terms and of the Sales Directives. ${ }^{5}$ Finally, in 1999-2000, the Sales ${ }^{6}$ and the E-Commerce Directives ${ }^{7}$ were adopted. These pairs of directives are important mainly for the following reasons. Standard contract terms and sales

Principles of European Contract Law, part III (The Hague: Kluwer Law International, 2003) (all contracts); on these principles, for instance, M. Hesselink / G. de Vries (eds), Principles of European Contract Law (The Hague: Kluwer Law International, 2001); R. Zimmermann, 'Die "Principles of European Contract Law", Teile I und II', (2000) Zeitschrift für Europäisches Privatrecht 391.

4 See Council Directive 87/102/EEC of 22 December 1986 for the approximation of the laws, regulations and administrative provisions of the Member States concerning consumer credit, OJ EC 1987 L 42/48; amended in OJ EC 1990 L 61/14 and 1998 L 101/17; important amendments proposed in OJ EC 2002 C 331 E 200, COM (2002) 443 final; see also Council Directive 85/577/EEC of 20 December 1985 to protect the consumer in respect of contracts negotiated away from business premises, OJ EC 1985 L 372/31; Council Directive 86/653/EEC of 18 December 1986 on the coordination of the laws of the Member States relating to self-employed commercial agents, OJ EC 1986 L 382/17. A 'core' directive - related to contracts - is as well the Product Liability Directive, OJ EC 1985 L 210/29.

5 The Green Paper on standard contract terms was published in 1990, OJ EC 1990 C 243/2; COM (90) 322 final - SYN 285. It led to the Council Directive 93/13/EEC of 5 April 1993 on unfair terms in consumer contracts, OJ EC 1993 L 95/29. Soon afterwards, on 15 November 1993, the Green Paper on sales law and after sales services was published, followed by a second one in 1995: COM (93) 632 final; COM (95) 520 final.

6 Directive 1999/44/EC of the European Parliament and of the Council of 25 May 1999 on certain aspects of the sale of consumer goods and associated guarantees, OJ EC 1999 L 171/12. Monographs on the directive by: G. de Cristofaro, Difetto di conformità al contratto e diritti del consumatore - l'ordinamento italiano e la direttiva 99/44/CE sulla vendita e le garanzie dei beni di consumo (Padova: Cedam, 2000); M. Bianca / S. Grundmann (ed), EU Sales Directive - Commentary (Cologne: Schmidt, 2002); S. Pelet, La garantie légale des biens de consommation - étude comparée des droits français, anglais et communautaire (Villeneuve d'Ascg: Presses universitaires du Septentrion, 2003); A. Orti Vallejo, Los defectos de la cosa en la compraventa civil e mercantil. El nuevo régimen jurídico de las faltas de comformidad según la Directiva 1999/44/CE (Granada: Ed Comares, 2002); T. Repgen, Kein Abschied von der Privatautonomie - die Funktion zwingenden Rechts in der Verbrauchsgüterkaufrichtlinie (Lübeck: Schöning, 2001).

7 Directive 2000/31/EC of the European Parliament and of the Council of 8 June 2000 on certain legal aspects of information society services, in particular electronic commerce, in the Internal Market ('Directive on electronic commerce'), OJ EC 2000 L 178/1; see also Directive 1999/93/EC of the European Parliament and of the Council of 13 December 1999 on a Community framework for electronic signatures, OJ EC 2000 L 13/12. 
on the one hand constitute the typical form in which contracts are concluded nowadays and the basic classic contract type. Moreover, the Sales Directive contains the one most important model existing in EC Law on standards of performance and breach of contract. The Sales and the E-Commerce Directives on the other hand, in their combination, contain probably the most important bits of a model on formation of contracts in EC Law. Now, these two - formation on the one hand and performance and breach on the other - constitute the core areas of any contract law. And the last five years? They seem to be the era in which a European Contract Code became a realistic perspective. Some important aspects have been decided as well, in particular that it should be an optional instrument. ${ }^{8}$

These developments provide more than sufficient reason to stand back and reflect on what could be learnt ... from the harmonisation process, from the less than expected success of the CISG, from the Unfair Contract Terms, the Sales and the E-Commerce Directives and from so many other developments ... for the colour which European Contract Law has today (see below section II) and that which it should have tomorrow (see below section III).

8 The most important steps are the decision taken by the Council on the Tampere summit: European Council of Tampere 1999, SI (1999) 800, n 39; and then three 'communications' by the EC Commission: Communication of the Commission to the Council and the European Parliament on European Contract Law, COM (2001) 398 final = OJ EC 2001 C 255/1; the international discussion can be found in: S. Grundmann / J. Stuyck (ed), An Academic Green Paper on European Contract Law (The Hague, et al: Kluwer, 2002); Communication of the Commission to the Council and the European Parliament - a more coherent European Contract Law, Action Plan of 12 February 2003, COM (2003) 68 final = OJ EC 2003 C 63/1; short survey by D. Staudenmayer, 'Der Aktionsplan der EG-Kommission zum Europäischen Vertragsrecht', Europäische Zeitschrift für Wirtschaftsrecht 2003, 165; Communication of the Commission, European Contract Law and the revision of the acquis: the way forward, COM (2004) 651 final. The European Parliament had already taken resolutions, at that time still of little political relevance: Resolution of the European Parliament of 26 May 1989 on the Endeavours to Harmonise Private Law in the Member States, OJ EC 1989 C 158/400; Resolution of the European Parliament of 6 May 1994 on Harmonisation of Certain Areas of Private Law in the Member States, OJ EC 1994 C 205/518. And it answered to the first communication by the Commission in Decision on the Approximation of Civil and Commercial Laws of the Member States, OJ EC 2001 C 140E/538. 


\section{Existing European Contract Law}

\section{Questions of the Two-Level System: Mainly Fundamental Freedoms and EC Secondary Law}

Contract law on the EC level and contract law on the national level interact already today (and as well national contract laws between them). These are not merely questions of conflict of laws which have nothing to do with the core substantive law question of how to strike the balance between freedom of contract and need for protection. Conflict rules - via party autonomy can extend contractual freedom, and many authors have stressed the potential of deregulation inherent in fundamental freedoms. Conversely, an international setting can also cause additional needs for protection, for instance with respect to informational problems. It is probably in the European private law discussion that the old - comfortable, yet artificial - split between conflict of laws and substantive law has largely been overcome. The three key elements in this respect are fundamental freedoms as applied in unharmonised areas, traditional conflict of law rules (mainly in the Rome Convention), and the interplay between fundamental freedoms and substantive contract law harmonisation in EC secondary law.

\section{a) Fundamental Freedoms and Unharmonised Areas}

Today, the starting point is evident. Contract law rules - both conflict rules and substantive law - are subject in principle to a scrutiny under the fundamental freedoms. ${ }^{9}$ On the other hand, it is also clear that contract law remains largely unaffected by an application of fundamental freedoms to unharmonised areas. The reason for this is mainly that the ECJ does not test contract law rules which are not internationally mandatory, ${ }^{10}$ ie all rules which do not fall

\footnotetext{
9 There are now two large monographs on the topic: O. Remien, Zwingendes Vertragsrecht und Grundfreibeiten des EG-Vertrags (Tübingen: Mohr-Siebeck, 2003) (book review in this issue); and also T. Körber, Grundfreibeiten und Privatrecht (Tübingen: Mohr-Siebeck, 2004) 492-503, 582-618. Seminal contributions to the debate are M. Fallon, 'Les conflits de lois et de jurisdictions dans un espace économic intégré - l'experience de la Communauté Européenne’, (1995-I) 253 Recueil des Cours 9; A. Fuchs / H. Muir Watt / É. Pattaut (eds), Les conflits de lois et le système juridique communantaire (Paris: Dalloz, 2004). In the latter (p 5) also my contribution on 'Internal Market Conflict of Laws - From Traditional Conflict of Laws to an Integrated Two Level Order' where abundant references for the following can be found.

10 Case C-339/89 Alsthom Atlantique [1991] ECR I-107 124 (ECJ). For a justification see Remien, $n 9$ above, 186-192; S. Grundmann, 'The Structure of European Contract Law', (2001) 9 European Review of Private Law 505, 513 et seq. Remien exempts most of contract law from an in depth scrutiny under the fundamental freedoms for yet another reason, see book review in the next issue of this journal.
} 
under Article 5-7 Rome Convention. In other words, the ECJ will challenge only (national) consumer protection rules, labour law, and rules aiming at the protection of a general good, namely economic (antitrust law, monetary regulation etc). Thus, with respect to default rules and rules which are mandatory only in domestic cases, the fundamental freedoms have no deregulatory effect. And the rules which are internationally mandatory have virtually all been harmonised, so that the core question is that of applying the fundamental freedoms to harmonised areas (see below section c). In fact for unharmonised areas, Remien has challenged not much more than such exotic cases as the throwing of dwarfs and contracts for erotic services not paid in advance.

There is one exception, which is not strictly contract law. Rules on unfair competition law have been tested quite considerably ${ }^{11}$ (on the EC level, such rules can, of course, be found as well in contract law directives). It is in ECJ case law in this area mainly that some authors have found a 'dark side' of EC Law, ie where the need of integration is over-emphasised and thereby issues of (communicative and distributive) justice are neglected. ${ }^{12}$ Axa Royale Belge constitutes a core example and is a tough case indeed. ${ }^{13}$ Belgian law asked for a warning that, in life insurance contracts, changing the company later is costly. This rule applied also to foreign insurance companies. The ECJ struck down this rule as not being 'specific' enough. Fundamental freedoms require indeed that a national rule which may create a burden for cross-border offers be justified by mandatory reasons of public good. Consumer (and more generally clients') protection has been considered as such a reason. ${ }^{14}$ For reasons

11 See, among many others: Case C-362/88 GB-Inno-BM [1990] ECR I-667 (ECJ); Case C-238/89 Pall v Dablhausen [1990] ECR I-4827 (ECJ); Case C-126/91 Yves Rocher [1993] ECR I-2361 (ECJ); joined Cases C-267/91 and C-268/91 Keck E Mithouard [1993] ECR I-6097 (ECJ); Case C-292/92 Hünermund [1993] ECR, I-6787 (ECJ); Case C-470/93 Mars [1995] ECR I-1923 (ECJ) and decisions quoted below n 31 and 34.

12 See the large monograph by Ch. Schmid, Die Instrumentalisierung des Privatrechts durch die Europäische Union: Privatrecht und Privatrechtskonzeptionen in der Entwicklung der Europäischen Integrationsverfassung (2005); some core ideas in the author's contribution to this issue. For the parallel question - asked for substantive EC contract law - see below section III, sub 3.

13 Case C-386/00 Axa Royale Belge [2002] ECR I-2209 (ECJ). The case is formally on an issue discussed below c) (there was harmonisation); in substance, however, it deals with a question of general good, because the relevant directive explicitly accepted additional national rules when justified by such reasons.

14 For consumer protection and rules against unfair competition: Case 120/78 Cassis de Dijon [1979] ECR 649, 662 (ECJ); Case 286/81 Oosthoek [1982] 4575, 4587 (ECJ). That professional clients' protection may be such a reason as well can be inferred from: ECJ the Ingmar case (see next n) and from Case C-288/89 Stichting Gouda [1991] ECR I-4007, 4041 (ECJ) ('professional standards' created for the protection of clients gener- 
to be mandatory, they must, however, be also as precise as possible and proportionate (limiting freedom of contract as an ultima ratio, for instance, only if information duties do not suffice). Even under this standard, however, it can be asked (1) whether the burden put on foreign insurance companies was really high (what was considerable was the warning or 'deterring' effect. ie the effect that clients could take the decision in a more rational way) and (2) whether an alternative, more precise rule would not put a higher burden on companies and might even lack the clear effect of a warning. In other words, it is questionable whether there was an impediment at all, and if so whether it was not justified. The core question raised by this case and others would seem to be whether the systematic framework has its defects or whether only the application in this one case is problematic. I would argue for the second conclusion. It serves 'justice' to force national legislatures to be as precise as possible and to test alternative instruments of protection - if one gives them a margin of discretion in evaluating the effects of the rule (as the ECJ did in a number of cases).

\section{b) Genuine Conflict of Law Rules}

This is, of course, not the place to discuss the Rome Convention. The two cornerstone decisions taken by this Act should, however, be remembered. On the one hand, cross-border contracts have been subjected to a system which in principle is liberal and provides for considerable legal security. Party autonomy is not subjected to provisos such as a test of whether the law chosen by the parties is fair, whether it has a relevant (close) relationship to the case etc. In its radical simplicity, this was new in conflict of laws, namely for common law jurisdictions. This decision, in secondary law, is much in line with the philosophy of fundamental freedoms in primary (EC Treaty) law, opening up markets. On the other hand, the most blatant protective needs have as well been safeguarded: the protection of consumers (Article 5), of labour (Article 6), and of the general good, typically economic, for the most part third party interests or macro-economic institutions (Article 7). For these individual persons (Articles 5 and 6) or types of general good (Article 7), the Convention guarantees the application of 'their' law (Articles 5 and 6) or the law affected (Article 7). And in the Ingmar case, the ECJ even extended this regime to weaker parties other than consumers, in this case commercial agents whom the court considered to be weaker than their principals. ${ }^{15}$

What is important about Ingmar is that the ECJ is willing to extend protective devices in conflict of laws beyond the limits set in the Rome Convention

ally), repeating, as many other cases, a long list, including also consumer protection and unfair competition.

15 Case C-381/98 Ingmar [2000] ECR I-9305 (ECJ). 
where policy considerations so demand and where they outweigh interests of freedom and legal security in international commerce. It is not so clear whether they really did so in this particular case. Again, the outcome in the particular case may be questionable, but the overall framework seems to be appropriate. The convention is weak on one point, because it does not decide the outcome of what might be the most important case in practice: how to deal with internationally mandatory rules in harmonised areas which go beyond the minimum level set by EC Law:

\section{c) Fundamental Freedoms and Harmonised Areas}

If only internationally mandatory rules have to be tested under the fundamental freedoms and if most of these rules in contract law are harmonised, the core question would seem to be how to handle national contract law deviating from the $\mathrm{EC}$ rule. A national rule which does not reach the minimum level set on the EC level just violates EC Law and is brought in line via different instruments (direct application, indirect effect, state liability). More interesting is more stringent national law. There are basically three approaches to this phenomenon: not to allow it (maximum or total harmonisation), ${ }^{16}$ to allow it and apply it in domestic and in cross-border cases (in the second case subject only to what has been said in section a) above) ${ }^{17}$ or to allow it, but apply it in domestic cases only, at least in principle. ${ }^{18}$

16 This is what parts of the EC Commission favour now, see, however, Art. 4 of the European Parliament and Council Directive 2002/65/EC of 23 September 2002 on distance marketing of financial services to consumers and amending Council Directive 90/619/ EEC and Directives 97/7/EC and 98/27/EC, OJ EC 2002 L 271/16 where a maximum approach had been proposed. And the ECJ, in a case on the Product Liability Directive (n 5), saw this measure (not explicit in its wording) as defining a maximum level as well: Case C-52/00 Commission v France [2002] ECR I-3827 (ECJ); Case C-154/00 Commission v Greece [2002] ECR I-3879 (ECJ).

17 B. Smulders / P. Glazener, 'Harmonization in the Field of Insurance Law through the Introduction of Community Rules of Conflict', (1992) 19 Common Market Law Review 775, 797; W.-H. Roth, 'Die Freiheiten des EG-Vertrages und das nationale Privatrecht - zur Entwicklung internationaler Sachnormen für europäische Sachverhalte’, Zeitschrift für Europäisches Privatrecht 1994, 5, 31 et seq; id, 'Transposing "Pointillist" EC Guidelines into Systematic National Codes - Problems and Consequences', (2002) 10 European Review of Private Law 761, 771-774; and further references in M. Dougan, 'Minimum Harmonization and the Internal Market', (2000) 37 Common Market Law Review 853, 870; also A. Baumert, Europäischer ordre public und Sonderanknüpfung zur Durchsetzung von EG-Recht - unter besonderer Berücksichtigung der sog. mittelbaren horizontalen Wirkung von EG-Richtlinienbestimmungen (Francfort: Lang, 1994) 232-234.

18 N. Bernard, 'The Future of European Economic Law in the Light of the Principle of Subsidiarity', (1996) 33 Common Market Law Review 633, 646 et seq; also P. Martin, 
The core idea of the solution named last (besides dogmatic arguments on the basis of Article 95 para $4 \mathrm{EC}$ e contrario) is the following. If the harmonisation measure did not really specify what is the general good which is strictly needed ('mandatory reasons') and if it did not exempt enterprises in crossborder transactions from additional requirements, then two basic principles of EC Law would be violated. No mutual recognition would be granted although all Member States had the chance to discuss and, even if in a minority, to use Article 95 para $4 \mathrm{EC}$; and the basic requirement of Article $95 \mathrm{EC}$ as a legal basis - facilitation of cross-border trade which may be supplemented, but not substituted by ideas of consumer protection - would not be satisfied. The measure would not give cross-border trade any additional freedom. Policy considerations confirm this view. Consumers - or other clients - are not a homogeneous group. Even if one neglected the interest of the supply side to market products on the basis of harmonised law only (if it exists), there would still be the interests of the demand side to consider. Not allowing foreign supply to shape the offer under its version of the harmonised law would deprive all (!) clients of the chance to profit from a better mix in another Member State ... only because some other clients may need more protection, ie the domestic standard of protection. It would seem to be preferable to allow clients to choose whether they really want to be protected (or potentially overprotected) by domestic law. Even less informed clients should be able to learn that there is this possibility and, if they are risk-averse, they have to stick to their home country protection, for instance German Law as opposed to say Irish Law. In large transactions, it may, for instance, pay to get professional advice but then opt for foreign standards.

'Le droit social communautaire: droit commun des Etats membres de la Communauté européenne en matière sociale?', (1994) 30 Revue trimestrielle de Droit Européen 609; most authors in German literature: A. Bleckmann, 'Probleme der Auslegung europäischer Richtlinien', Zeitschrift für Gesellschafts- und Unternebmensrecht 1992, 364, 373; S. Grundmann, 'EG-Richtlinie und nationales Privatrecht - Umsetzung und Bedeutung der umgesetzten Richtlinie im nationalen Privatrecht', Juristen-Zeitung 1996, 276, $277-$ 281; I. Klauer, 'General clauses in European Private Law and "Stricter" National Standards, The Unfair Terms Directive', (2000) 8 European Review of Private Law 187, 201210; E. Steindorff, Grenzen der EG-Kompetenzen (Baden-Baden: Nomos, 1990) 84; very thoroughly now K. Riesenhuber, System und Prinzipien des Europäischen Vertragsrechts (Berlin, et al: de Gruyter, 2003) 146-170; and, in a rather uniform way, Italian doctrine: see, for instance L. Mengozzi, 'La seconda direttiva bancaria: il mutuo riconoscimento e la tutela dell'interesse generale degli Stati Membri', (1994) Rivista di diritto europeo 447, 459 et seq. Hesitating between both strands: Dougan, n 17 above, 863-885. The case law is difficult to interpret, see Grundmann, $\mathrm{n} 9$ above. 
As in substantive EC Contract Law, the chance to find refined solutions satisfying not only one, but all groups in a market, to combine freedom and protection, should be seen as the most important challenge in a modern European Contract Law.

\section{EC Secondary Law on Market Order (Regulation of Contracts) or: the Question of Material Freedom}

\section{a) Survey on the Law}

Until the adoption of the Sales Directive in 1999, EC Contract Law was of a peculiar kind. It dealt little with the questions that traditional national contract laws are primarily concerned about, ie all the default rules (and some mandatory rules) on the issue of how the parties would have shaped their contract had they had perfect knowledge and had there been enough competition (no considerable restriction of competition). These rules mainly seek to mimic the consensus which the parties would have reached under ideal conditions. Conversely, EC Contract Law mainly dealt with re-establishing these two conditions which, if not met, make markets and the consensus mechanism (partly) fail: with information problems and restriction of competition. Therefore, one early seminal paper on EC Contract Law stated that contract law was approached in Europe 'from the boundaries' ('von den Rändern her'). ${ }^{19}$

In fact, many directives almost exclusively aim at levelling out information asymmetries. ${ }^{20}$ This is the case for the most important sector specific tools, the Package Travel, Timeshare, and (so far) also the Consumer Credit Directives and - to a lesser extent - also the Investment Services (now: Markets in Financial Instruments) Directive. The same is true for the directives dealing with specific marketing techniques - the Doorstep and the two Distance Selling and Marketing Directives - which all contain a revocation right as key tool. This right can be seen in fact as an information rule. It aims at giving the

19 Ch. Kirchner, 'Europäisches Vertragsrecht', in L. Weyers (ed), Europäisches Vertragsrecht (Baden-Baden: Nomos, 1997) 103, 106; see then more extensively Grundmann, $n$ 10 above, 505.

20 The two early overall commentaries are C. Quigley, European Community Contract Law (Oxford: OUP, 1997); S. Grundmann, Europäisches Schuldvertragsrecht (Berlin, et al: de Gruyter, 1999, $2^{\text {nd }}$ ed announced for 2005). References for all measures named in the following can be found there. For an interpretation of European Contract Law as focusing very much on the information problem: S. Grundmann / W. Kerber / S. Weatherill (eds), Party Autonomy and the Role of Information in the Internal Market (Berlin, et al: de Gruyter, 2001) (see the introduction by the editors, in a modified version also in: (2002) 39 Common Market Law Review 269). 
client an additional period for gathering information because the use of this marketing technique deprived him of the chance to inform himself properly. Also the one important non sector specific directive remaining (until 1999), the Unfair Contract Terms Directive, dealt with information problems. It differs from the other measures though, because here, the information asymmetry is considered to be insuperable. As a consequence, the Unfair Contract Terms Directive does not prescribe primarily the giving of information but rather sets - paternalistically that is in a mandatory rule - the standard to be observed. The overall picture thus shows many directives which mainly adhere to the idea of helping the market (when it partly fails) by levelling out information asymmetries and then leaving contract freedom reign sovereign again, and one directive where the market is substantially corrected - and this area is indeed very important: As contracts typically contain standard terms to a large extent, correcting the market in this respect means that quite substantially there is 'quasi-mandatory' law, set for paternalistic reasons (leaving contract freedom intact only within very narrow margins). ${ }^{21}$

A second block of legal measures dealt with direct and indirect restrictions of competition, most clearly the block exemptions which had the effect of creating standard forms which businesses had to accept if they wanted to profit from the exemption (and which have this effect still today, though less noticeably). The rules on public procurement and on copyright questions (mainly relating to software) are also related to competition.

\section{b) Contract Freedom as the Starting Point?}

Contract freedom has certainly been conceived in a more formal way in 19th century liberalism. The German Civil Code has often been characterised (and criticised) as being the typical offspring of this era. ${ }^{22}$ Formal consensus was seen as paramount. ${ }^{23}$ Conversely, in the late 20th century, important contract

21 M. Hesselink, 'Non-Mandatory Rules in European Contract Law', (2005) 1 European Review of Contract Law 44, 66-68. For the reasoning - also economic - why standard contract terms have to be scrutinized so narrowly: M. Adams, 'Ökonomische Begründung des AGB-Gesetzes - Verträge bei asymmetrischer Information', Betriebsberater 1989, 781, 787; and H.-B. Schäfer / C. Ott, Lebrbuch der ökonomischen Analyse des Zivilrechts ( ${ }^{\text {rd }}$ ed, Berlin: Springer, 2000) 478-480.

22 F. Wieacker, Das Sozialmodell der klassischen Privatrechtsgesetzbücher und die Entwicklung der modernen Gesellschaft (Karlsruhe: C.F. Müller, 1953); R. Zimmermann, 'Foreword', in F. Wieacker, A History of Private Law in Europe (Oxford: University Press, 1996).

23 A good example in this sense can be found in recent case law of the German Supreme Court for private law matters, the Bundesgerichtshof, Nene Juristische Wochenschrift 1994, 1278; 1994, 1341 and 1994, 1726. The judgment has, however, been struck down 
law scholars in the United Kingdom and on the continent saw a strong trend towards materialisation and even the fall of contract freedom..$^{24}$ It seems, however, that contract freedom, though possibly weakened in legislation and contested in theory if it is conceived too formally, has not seriously been challenged as a starting point. This is for good cause. (1) The principle of subsidiarity in its radical form vests the power to decide with those affected - the parties to the contract -, at least if they can sensibly do so and do not affect others. As a consequence, the legislature has to look first for a rule which empowers the parties to take such decisions and, only if this fails, to step in paternalistically with its own mandatory substantive solution. It has to justify paternalistic action, which sets aside the intentions of the parties. (2) The legislature is far from being capable of capturing the large variety of heterogeneous preferences. Planning for a national economy has proven clearly suboptimal in practice. Competition, and in particular freedom of contract, have indeed proven to be probably the most powerful discovery device. ${ }^{25}$

Therefore in principle, legislatures should not have the say, and often they do not even have (superior) knowledge. The real question is not whether freedom of contract has to be the starting point, but how formally it may be conceived, or how much materialisation is needed, is acceptable, and can be justified.

\section{c) From the Liberal Formal Concept of Freedom to Material Freedom - Towards a Common Analytical Framework?}

On precisely this question, the role of EC Contract Law is highly debated. Is it neo-liberal so that it goes too far in deregulation, or is it interventionist, thereby exaggerating materialisation? ${ }^{26}$ In the following, it is argued that the

on constitutional grounds, namely as violating fundamental values of social justice: Bundesverfassungsgericht, BVerfGE 89, 214 and Neue Juristische Wochenschrift 1994, 2749.

24 P. S. Atiyah, The Rise and Fall of the Freedom of Contract (Oxford: OUP, 1979); see also F. H. Buckley (ed), The Fall and Rise of Freedom of Contract (Durham: Duke U. P., 1999); C.-W. Canaris, 'Wandlungen des Schuldvertragsrechts - Tendenzen zu seiner "Materialisierung”', (2000) 200 Archiv für civilistische Praxis 276.

25 F. v. Hayek, 'Wettbewerb als Entdeckungsverfahren', in id, Freiburger Studien-Gesammelte Aufsätze (2 ${ }^{\text {nd }}$ ed, Tübingen: Mohr-Siebeck, 1994) 249.

26 From the host of literature, see, for instance, on the one hand Wilhelmsson, 'Varieties of Welfarism in European Contract Law', (2004) 10 European Law Journal 712; on the other Canaris, n 24 above; M. Martinek, 'Unsystematische Überregulierung und kontraintentionale Effekte im Europäischen Verbraucherschutzrecht oder: weniger wäre mehr', in S. Grundmann (ed), Systembildung und Systemlïcken in Kerngebieten des Europäischen Privatrechts - Gesellschaftsrecht, Arbeitsrecht, Schuldvertragsrecht (Tübingen: Mohr-Siebeck, 2000) 511. See also the sources cited below n 41 above. 
EC legislature - in contract law - rather found an equilibrium ... not in all individual cases, but in principle and approach.

Some striking examples first. On the one hand, EC Sales Contract Law has convincingly been interpreted as switching from caveat emptor as key principle to caveat praetor. ${ }^{27}$ And sales is still the core contract type. It is also clear that the whole regime of pre-contractual information on the EC level goes far beyond what was normal in national contract laws. ${ }^{28}$ On the other hand, EC Contract Law is not heavily interventionist either. Besides mandatory information duties which prepare a contract then formed by party agreement, it does not contain many mandatory rules fixing the content of the contract, thereby replacing party agreement. The one important exception (until 1999), standard contract terms, can well be justified also on the basis of information economics (n 22).

Two ideas could at least simplify the discussion. The first is to use one and the same analytical framework which would help to make arguments match even though they may then still point in the direction of more or of less materialisation; and, secondly, to specify on this basis which situations and problems are really meant and to keep these situations analytically segregated (no overall 'ideological' arguments). I will try to exemplify this in the area of consumer law which is particularly disputed (see below d).

In my view, institutional economics is particularly helpful as a normative analytical framework (despite some weak points). Institutional economists have isolated a certain number of conditions which, if satisfied, should lead to 'perfect contracts'. Even though they hardly ever all are met, the list helps to isolate the problem(s) in particular cases or areas. The list as such is largely accepted, although classifications somewhat vary. One list would be: parties have unconstrained freedom of choice (subject only to the proviso that their resources are limited); perfect competition; absence of transaction costs; the contract does not cause externalities (third party effects, positive or negative); perfect information of the parties acting; and rational agents..$^{29}$ Markets (and

27 S. Hedley, 'Quality of goods, information, and the Death of Contract', (2001) Journal of Business Law 114, esp 123. This change can well be justified on economic grounds (institutional economics): see F. Gomez and S. Grundmann, in Bianca / Grundmann, n 6 above, Introduction para 74-77 and Art 2 para 4 respectively.

28 See, for a particularly clear example, the comparison with Italian Law, V. Roppo, 'Formation of Contract and Precontractual Information from an Italian Perspective (Final Remarks from the Perspective of European Contract Law)', in S. Grundmann / M. Schauer (eds), The Architecture of European Codes and Contract Law - Structures and Contents (The Hague, et al: Kluwer, 2005) forthcoming.

29 M. Fritsch / T. Wein / H.-J. Ewers, Marktversagen und Wirtschaftpolitik ( $5^{\text {th }} \mathrm{ed}, \mathrm{Mu}-$ nich: Vahlen, 2003) 89-362; A. Hatzis, 'Civil Contract Law and Economic Reasoning: 
the consensus mechanism) do not function 'perfectly' unless all these conditions are fully satisfied. The more that concrete market conditions deviate from the model, the more markets tend even to fail.

Only a few of these conditions are really at stake when contract freedom and materialisation are discussed. The issue is really concerned with questions of restriction of competition, nor minimisation of transaction costs which is an important scope for the design of default rules, and not even causation of external effects either (which in contract law are less important because of the principle of privity). The three other conditions are indeed paramount for a functioning of the consensus mechanism: availability of all material information, capacity to act rationally (with problems of bounded rationality), and absence of constraints (besides scarcity). Unless a coherent alternative analytical framework is proposed, it would already be very helpful to discuss along these lines.

Apart from isolating these types of market failures, institutional economics stresses for good reason the following points. (1) Any change in the institutional, namely legal framework, must be justified by showing that an alternative solution can be proposed which is superior to the one existing, considering the interests of all parties affected (no 'Nirvanha' approach which excludes a less than perfect solution without naming alternatives). (2) It has to be accepted as a starting point that the conditions of perfect contracts are hardly ever met and that therefore freedom of contract is never fully achieved, but (3) that imperfections are not necessarily best handled by limiting contract freedom either. In other words, although the conditions of perfect contracts are not met, the deviations from this model have to be weighed and set off against the disadvantages of limiting freedom of contract. In fact, this is a very open-ended analytical framework and a very pragmatic one.

The main disadvantages of paternalistic mandatory rules are that the variety of offers is reduced to one (no heterogeneity) and that the persons who bear

An Unlikely Pair?', in Grundmann / Schauer, n 28 above, forthcoming. On information problems as the core problem discussed in the following: H. Fleischer, Informationsasymmetrie im Vertragsrecht (Tübingen: Mohr-Siebeck, 2001); Grundmann / Kerber / Weatherill, $\mathrm{n} 20$ above. This does not seem to be too far from what is meant by replacing or supplementing the concept of capacitas (which is quite formal and excludes only rather extreme cases) by a more meaningful concept of 'capability' in which one would ask whether the conditions that a party was capable to take decisions in a sensible way were really met: see A. Sen, Development as Freedom (Oxford: OUP, 1999); id, 'Development and Capability Expansion', (1989) 19 Journal of Development Planning 41. The law should then look for enhancing this capability, for instance via information rules. 
the consequences no longer decide. Conversely, the prime problem of having the parties themselves decide (besides isolated cases like externalities and restriction of competition) is that they are not able to decide because they lack the material information, or are unable to process it (bounded rationality), or they are not free to decide. These are the three 'consensus failures' possible. From this perspective, the first step must, of course, be to cure these consensus failures, and, even where this was possible only to a limited extent, to weigh the (remaining) disadvantages of both possibilities: leaving contract freedom intact - helped by market enhancing rules - or substitute it with a paternalistic (outside) solution. Minor deviations from the model would typically speak for using only market enhancing instruments and otherwise to let the parties decide. In case of more important deviations, the legislature would still have to look for market enhancing tools first, and in all cases to ask whether it has an alternative solution which on balance is better for the total of the groups affected than an acceptance of the results produced by imperfect markets.

\section{d) The Example of Consumer Law, Mainly Consumer Credit}

Taking the typical example of consumers - or more generally weaker parties -, may exemplify what has been said.

The interests involved must be the starting point. Typically two sets of interests are named: the interest on the side of supply to shape the contract freely in order to create different offers; and the interest on the side of demand to be protected against consensus failure, namely consumers, most particularly those less well-informed. This analysis is incomplete. Clients are far from forming a uniform group; their interests diverge considerably, even if one only considers consumers. Some consumers certainly like to compare prices and other conditions, perhaps surfing on the internet. Others do not or can not. It seems difficult to justify disregarding the interests of the first group they might be happy with information duties only -, if the interests of the second group can be taken care of as well. This would run counter what Drexl has called the fundamental right of economic self-determination of consumers. ${ }^{30}$ Why should a - well-informed - consumer have to lose his right to choose an Irish insurance policy only because others do not want, or even are not able, to inform themselves? Why not give him this right at least if he consults an independent information intermediary? Why not copy the approach

30 J. Drexl, Die wirtschaftliche Selbstbestimmung des Verbrauchers - eine Studie zum Privat- und Wirtschaftsrecht unter Berücksichtigung gemeinschaftsrechtlicher Bezüge (Tübingen: Mohr-Siebeck, 1998). 
from investment services and give more freedom, if a consumer has proven to be experienced?

What is needed is a chance for everybody to have his interests safeguarded. The debate on the concept of the 'reasonably well-informed' consumer is to the point. The ECJ first developed the concept when applying fundamental freedoms, mainly in the Cassis de Dijon case (n 14 above), justifying the supremacy of information rules where they can cure the market failure. Then the concept has been applied to the Directive on Advertising: ${ }^{31}$ advertising must (only) be such not to mislead a 'reasonably well-informed' consumer. Comparative advertising was one of the key issues. Forbidding it - because some consumers do not consider the offers with 'reasonable' care -, forecloses in good part what is the key source of information today (we watch TV but do not read instructions) and what is a key tool for newcomers entering the market. It thus has adverse effects on information and competition.

So far, these examples have been mainly concerned with lack of information, the first source of 'consensus failure'. This problem is relatively easy to deal with in principle. And EC Contract Law deals with it quite consistently. Although some information rules might go too far, one can rather clearly distinguish the following principle. The rules typically ask the party who has much easier access to information to give all material information; to give it in a clear and transparent way (not too much, on a permanent support); and to give it only if the other side does not have similarly easy access to it. In a future Code, this could even be specified in such a general way, distinguishing moreover between information which is at hand and that which needs to be gathered, and adding specifications (lists) for particular cases.

It is more difficult to deal with the rationality requirement. On the one hand, there is a host of examples where people - not only consumers - systematically do not decide rationally. ${ }^{32}$ On the other hand, such an evident device as

31 Council Directive 84/450/EEC of 10 September 1984 relating to the approximation of the laws, regulations and administrative provisions of the Member States concerning misleading advertising, OJ EC 1984 L 250/17; amended in OJ EC 1997 L 290/18 (now including comparative advertising); see Case Clinique [1994] ECR I-317, 318 and 336 (ECJ); Case Unilever [1999] ECR I-431, 432 (ECJ); and decisions named in n 34 above; for a critique of the concept see, for instance, S. Weatherill, 'Prospects for the Development of European Private Law Through 'Europeanisation' in the European Court - the Case of the Directive on Unfair Terms in Consumer Contracts', (1995) 3 European Review of Private Law 307, 312-318.

32 There is a host on literature on bounded rationality and other problems with this requirement in (and outside) institutional economics. See only J. Rachlinski, 'A Positive psychological Theory of Judging in Hindsight', (1998) 65 University of Chicago Law Review 571; Th. Ulen, 'Information in the Market Economy - Cognitive Errors and Legal 
information rules is not at hand. Professional help is often a tool also in this respect - like for the gathering of information. And professional help could serve freedom of contract again in many respects. Negotiating standard contract terms between the two sides of the market - and perhaps on a European scale - is one important example where consensus supported by expertise could lead to a safe harbour for the agreement reached. ${ }^{33}$ Again, the goal would be to look for tools for minimising consensus failure in order to profit more extensively from the advantages of contract freedom.

There is one more consideration ... of principle. Consider once again (comparative) advertising, which may mislead some less well-informed consumers. Is it not a problem that some are mislead if the standard is set at a more demanding level, even though others gain, because they get more meaningful information? The answer is yes and no. Bounded rationality is a disadvantage generally in life: in finding good opportunities (irrespective of contracts), in getting good jobs etc. Thus, if contract law asks consumers to invest some effort in the processing of information, it only copies a more general fact of life $\ldots$ with the effect of giving others more chances. Two questions would then stand out. Have the gains and the losses been set-off in an acceptable way (the criterion used in economics, the balance of both in 'Dollar votes' gives some indication, not necessarily the solution)? And is there a 'safety net' for those loosing? If the second condition is met, creating losses for some, but gains for others and for markets needs to be accepted if an increase in overall wealth is accepted as a goal (polls would seem to indicate that more than two thirds in typical western populations think so). Combining complete protection of one side of the market and economic dynamics and growth are a Nirvanha idea. Indeed, EC Contract Law and its institutional framework provide for such a 'safety net' - although they do not protect all consumers in all instances. These 'safety nets' are rarely taken into account in academic debates. Apart from 'social' tax law and social security - for which the Member States still have the prime responsibility -, mainly two devices should be named. The ECJ does not apply the concept of the 'reasonably well-informed' consumer throughout, namely not where health and life are at stake. ${ }^{34}$ These are

Correctives', in Grundmann / Kerber / Weatherill, n 20 above, 98, 111-127 ('hindsight bias', 'overconfidence', availability and 'representativeness'); N. Weinstein, 'Unrealistic Optimism about Future Life Events', (1980) 39 Journal of Personality and Sociol Psychology 806.

33 H. Collins, 'The Freedom to Circulate Documents: Regulating Contracts in Europe', (2004) 10 European Law Journal 787; Commission Action Plan, n 8 above, n 36 et seq; see as well contribution by $\mathrm{S}$. Wittacker on this question in issue 4 of this year.

34 Case C-220-98 Estée Lauder [2000] ECR I-117, 146 (ECJ); Case C-99/01 Linhart and Biffl [2002] ECR I-9375, 9404 (ECJ). 
too existential a good not to care about bounded rationality. And existential risks arise as well in case of economic loss. Typically, loss goes beyond single individual cases when not only financial means already present are lost, but when also the potential of future income is consumed. Here, consumer credit transactions are paramount. And although the Consumer Credit Directive of 1986 has installed an important informational tool, making prices easily comparable for the first time and specifying the overall burden in 'good times', additional rules would seem to be needed. ${ }^{35}$ In another respect, the 'safety net' is already meaningful on the EC level. Consumer insolvency with a liberation from the residual debt after a number of years - even though based on national insolvency law - is recognised for the whole of Europe under the EC Insolvency Regulation. ${ }^{36}$ Risk of economic loss can certainly be substantial for consumers, but it is no longer unlimited in Europe. Such 'safety nets' and a more liberal consumer law, accepting that there be losers as well, would seem to correlate.

\section{EC Secondary Law on Classical Contract Law or the Question of Generalisation}

EC Contract Law first approached questions of classical contract law in the Sales and then the E-Commerce Directives, ie since 1999/2000. These concern questions of formation, performance and others where legislatures try to mimic what parties would have decided themselves had they drafted a complete contract. The fact that this happened so late comes as a surprise given that national contract laws traditionally focus on this area. The answer nor-

35 One could either ask credit institutions to give at least examples of what will happen if the credit is not paid back (in case of divorce, unemployment etc), or one could even ask that the credit institutions somehow have a (shared) responsibility in the question whether the client can 'afford' the credit. See on all these ideas: K. Riesenhuber, 'Information - Beratung - Fürsorge. Kritische Bemerkungen zum Vorschlag einer neuen Verbraucherkreditrichtlinie' and J.-U. Franck, 'Bessere Kreditkonditionen für Verbraucher durch mehr Regulierung - zum Paradigmenwechsel im Vorschlag für eine neue Verbraucherkreditrichtlinie vor dem Hintergrund der ökonomischen Theorie', Zeitschrift für Bankrecht und Bankwirtschaft 2003, 325 and 332. Finally, one should probably extend the safeguards also to the financing of land.

36 Mainly Art 16, 17 and 25 of the Council Regulation (EC) 1346/2000 of 29 May 2000 on insolvency proceedings, OJ EC 2000 L 160/1; see A. Wood, 'Improving Efficiency and Effectiveness: The EU Council Regulation on Insolvency Proceedings', (2003) 23 Business Law Review 230; S. Homann, System der Anerkennung eines ausländischen Insolvenzverfahrens und die Zulässigkeit der Einzelrechtsverfolgung - eine Untersuchung der neuen Rechtslage unter Berücksichtigung des Europäischen Insolvenzübereinkommens (Dissertation Münster, 2000). 
mally given is that classical contract law does not form an impediment to cross-border trade, at least not as an important one as consumer contract law, because it is not internationally mandatory. There is something to this argument, although the Sales Directive is still focused on consumers, but is general contract law in character. The development might also have to do with institutions. The DG Internal Market was more interested in company law and financial institutions ... and was solely responsible for the E-Commerce $\mathrm{Di}$ rective. The DG Consumers and Health did not really seem to be in a position to develop general contract law. Even today it is difficult to explain why this Directorate should steer the process of a European Codification - aimed at safeguarding the interests of all parties - and not, say, the competence of the DG Enterprises or - really neutral - of the DG Justice.

The solutions found in the two directives can not be discussed in detail here. There is a host of literature to each of them, monographs and a commentary on the Sales Directives, and even a number of commentaries on the CISG as its model. ${ }^{37}$ A separate paper (or book) would have to describe why the Sales Directive contains the one most important model in EC Law on standards of performance and breach of contract, how far it reaches and where are its shortcomings. And similarly, what is achieved by the Sales and the E-Commerce Directives, in their combination, for a model for the formation of contracts. In these respects, only some hints can be given for what is probably the key question for the development of this body of the law ... and at least one example which seems paradigmatic in several respects.

The key question, in my view, is whether the rules contained in these two directives (and others) can be generalised. This question has several aspects. First of all, large scale generalisation of the acquis communautaire is possible only if one can generalise from a consumer law measure. My opinion (last note above) is that this is possible. The simple answer would be that nothing in the Sales Directive is consumer law - all solutions but two or three new ones are virtually identical with those contained in the CISG, designed for commercial contracts - and that the E-Commerce Directive applies to other clients anyhow. Therefore, if one focuses on the core directives, the question really arises only with respect to standard terms. More generally, however,

37 For my own interpretation of the Sales Directive see mainly: Bianca / Grundmann, n 6 above; S. Grundmann, 'Consumer Law, Commercial Law, Private Law - how can the Sales Directive and the Sales Convention be so similar?', (2003) 14 European Business Law Review 237 (with further references). Seminal for the CISG: J. Honnold, Uniform Law for International Sales (3 ${ }^{\text {rd }}$ ed, Boston: Kluwer, 1999); U. Magnus, in J. Staudinger, Wiener UN-Kaufrecht (CISG) (13 ${ }^{\text {th }}$ ed, Berlin, et al: de Gruyter, et al, Neubearbeitung 1999); P. Schlechtriem, Commentary on the UN Convention on the International Sale of Goods (CISG) (Munich: C. H. Beck, 1998). 
consumer law is specific mainly with respect to the informational situation of consumers and therefore a Code would have to distinguish virtually only with respect to information rules and - if they fail - some paternalistic mandatory safeguards. All the rest of contract law, distributive and commutative justice, is general, not role specific. Integrating consumer and 'other' contract law, has huge advantages. It brings all the material into the core discussion circles (no marginalisation of consumer law); and when rules are always put 'side by side', the community is forced more visibly to justify any rule which would treat one group differently from the other (coherence in the underlying value judgments). A second aspect - of similar importance - would concern how far one can generalise from specific types of contracts to others and to contract law generally. Many measures so far are sector specific or deal with a specific type of contract. And given that a European legal scholarship is still in statu nascendi, it would in fact seem preferable to build system first on the basis of more concrete examples, ie specific types of contracts, and create general contract law only by way of induction. A third aspect - probably less important would then be the inner coherence of the acquis communautaire. This issue concerns how far certain rules do not have too restricted a scope of application, for instance the measures on specific marketing techniques, and in how far rules contained in these measures are contradictory.

One example taken from the Sales Directive may be illustrative of another important challenge which one will have to face when systemising the acquis. The question is how to integrate rules which are regulatory in character and classical default rules. Article 2 para 2 lit $\mathrm{d}$ of the Sales Directive gives an example of how default rules, market enhancing rules and even market correcting rules might be integrated. Given the importance of regulation for modern contract law, this should be one of the aims of a European codification. According to this rule, information given by way of publicity (and even by other partners in the distribution chain) is binding on the seller unless corrected explicitly in the negotiation process; and this consequence can not be excluded, at least not in standard contract terms, probably not even by individual agreement (Article 7 Sales Directive). This example combines several aspects. It is very much about the change from the caveat emptor to the caveat praetor principle. The rule is also well grounded in policy considerations because the seller can more easily detect the problem and react to it. And the example integrates really all three types of rules. It helps to mimic what the parties would have agreed on, had they had complete information. It helps to do so by overcoming an informational problem which many traditional contract laws had, because they split the pre-contractual phase into a pre-negotiation phase where no individual legal relationship existed yet and a negotiation phase which was treated as if a contract already existed. Policy con- 
siderations would speak in favour of applying contractual remedies in the earlier phase if material information for the contract is given in this phase. The rule thus also has the potential of enhancing market mechanisms. And finally, the rule even corrects the market insofar as it does not allow any deviation .... again for good reasons.

\section{Some General Lines}

Summarising roughly what can be concluded from the explanations above, one would stress the following points. The acquis, at least in the examples named, tries to reach an equilibrium between freedom and safeguards. It is neither based on neo-liberal laissez faire nor heavily interventionist. More generally, it tries to integrate regulatory needs and classical default rules. The Sales Directive is a good example; others are the Commercial Agents Directive as interpreted in the Ingmar case and also the block exemptions. Integration of these two most important blocks of modern contract law is indeed one of the 'great' challenges of our times. And although the acquis tries to integrate both in some instances, there is still no 'coherent system' in this respect. Another important plea would be to create more safe harbours (recognition in all Member States) - were both sides of the market to have participated materially in the consensus. In all this, substantive law - both regulation and default rules - and the question of jurisdictional competition in a two-level system have to be considered in an integrated way. One has to think integration, markets, and jurisdictional competition ... in a system of European Contract Laws.

\section{Future European Contract Law}

A European Contract Code is on the agenda now, even though the EC Commission still prefers to speak vaguely of a Common Frame of Reference. ${ }^{38}$ The CISG as the most important international contract law unification measure has some success after 25 years, but still not as much as one would expect of the unification of the most important contract in 67 states which ratified the convention. The question is what to learn from this experience. More intensive discussion of this question is needed. A few words must suffice here. ${ }^{39}$

38 H. Collins, 'The "Common Frame of Reference" for EC Contract Law: A Common Lawyer's Perspective', in M. Meli / M. Maugeri (eds), L'armonisazzione del diritto privato europeo (Milano: Giuffrè, 2004) 107.

39 As to section 1., see more in detail S. Grundmann / W. Kerber, 'European System of Contract Laws - a Map for Combining the Advantages of Centralised and Decentralised 


\section{Optional}

All EC legislative organs have now decided to introduce a European Contract Code on an optional basis only, more precisely, on the basis that the parties can choose it. This would seem to be preferable indeed, at least in the short run (in my view also in the long run). This reduces adaptation costs and this does not waste huge costs of building up legal security, invested into national laws. Moreover, this gives more possibilities of continuous experimentation and of serving a larger variety of needs - advantages of large importance in volatile times with heterogeneous preferences.

What seems paramount for the success of the European Contract Code, if optional, is then the design of the options. 25 years of hesitant success of the CISG should be taken seriously. If national laws remain intact, the European Contract Code has to face competition. It would have to get at least the chance of developing similar formal qualities as these national Codes: There has to be the possibility that legal security develops. The first condition would seem to be a court of last instance which guarantees a uniform case law, a condition which has not been met in the case of the CISG, a condition, however, which might ask for some investment ... into a private law chamber at the ECJ. Even then, however, legal certainty requires case law and practice. The design of options in the case of the CISG seems to have had adverse effects in this respect as well. The CISG cannot be chosen for domestic cases (or only within the domestic law, like standard contract terms), and it was limited to commercial transactions. In both respects, a European Contract Code should do better. It should be eligible to be the choice of law of the parties even in purely domestic cases (potentially only on an opt-in basis). And it should cover all contracts, b2b and b2c. The latter is not only possible and desirable from a substantive law perspective (see above section II sub 3). The latter is as well the condition for one important change in the playing field. If indeed a European Contract Code could catch both national and international transactions and if it integrated all contracts, finding an equilibrium between freedom of contract and protective needs (material freedom), enterprises could subject all their business - Europe wide - to one set of rules and associations on the side of demand, for instance consumer associations, could give the advice to accept such a move. All this would have yet another consequence. It would speak as well in favour of a fully fledged system of contract law. This is a potential which the CISG does not have for the two reasons 
named, irrespective of the fact that in any case it covers only one type of contract.

The success of a European Contract Code will, however, probably not only depend on a more favourable design of options (giving it a similar possible reach as national laws). Considerable substantive qualities will be needed as well to 'prevail' in a process of competition. The qualities needed would seem to be a taking into account of tradition and of modern trends.

\section{Modern Trends and the Tradition}

a) Modern Trends

It seems obvious that a new Code should reflect modern trends adequately ... and not only copy, say, Code Civil (1804), Bürgerliches Gesetzbuch (1900) and Codice Civile (1942). This, however, may have important implications. The developments over the last 30 , perhaps 40 years, are such that traditional codes, even the Dutch Code, cannot really be taken as paradigms.

The pre-contractual phase has changed so radically with the rise of information society, information duties and the binding force of information given in the pre-contractual phase (including new media and publicity) that the boundaries and the time framework of contracts have to be given a new shape in a codified system. The paradigm of the individual contract is supplemented to such an extent by a practice in which contracts come in networks and chains, probably even in the majority of cases, that the individual contract and the network have to constitute two paradigms - on an equal footing - in a modern codified system. The same is true for the contract individually bargained for and the contract based on standard contract terms, again two paradigms have to be integrated into the codified system in parallel. A third and a fourth element would call as well for a change from a system based on one paradigm mainly to one based on two. First there is the dichotomy between consumer contract law and 'other' (or 'general') contract law, because of which problems will have to be solved with potentially diverging solutions for the two different settings; and, second, there is the dichotomy of spot contracts, namely sales contracts, and long-term, typically service contracts. This latter dichotomy would call for a new equilibrium in a specific part devoted to the single types of contracts.

All this will lead to a complex structure which needs most careful consideration and broad discussion, not just some marginal additions to traditional structures. All these developments have arisen in the last 30 to 40 years as a consequence of the movement from information society to service society, from mass transactions (standard contract terms and market expectations) to 
networks and hybrids. And - astonishing to some, although not far-fetched at all - all this has left much more prominent trace in the acquis communautaire (which just came of age, as explained in the introduction) than in traditional national codes or contract laws.

\section{b) A Tradition Developed Over Centuries}

On the one hand, there is a tradition developed over centuries. It will be difficult to organise the integration of this tradition. On the other hand, without it, ie concentrating on a comparative law bird's eye perspective, much of the treasures of several centuries of private law scholarship and practice will be lost. While inspiration and perhaps also principles are within the potential of comparative law studies, legal certainty and the coherence down into the last detailed ramification are much more based on the expertise of traditional, dogmatic private law thinking and practice, which has so far been confined to the national level. The potential of a Code - fostering equality and legal certainty $-{ }^{40}$ can be developed only if this part of the legal community is fully present for all major Member States or legal families. It may be painful to organise, but modern trends, tradition and a comparison of laws must meet. Only in this combination, supplemented by some interdisciplinary input, can an integrated and modern European Contract Law be developed.

\section{c) Material Freedom, Constitutional Values, Social Justice ${ }^{41}$}

From the aforesaid flows the following conclusion. A future European Contract Code must, of course, adhere to a concept of material, not formal freedom. Anything else would fall back behind the status reached over the last 30 years. What is important in every instance is to weigh the interests of the side of supply, typically professional, of the side of demand, often non-professional, and here both of those more capable of protecting themselves and less willing to accept mandatory limits and of those needing more protection (see above section 2 sub II). It would be socially unjust to neglect any of the interests named and, for instance, not to take into account in this respect the

40 D. Merten / W. Schreckenburger, Kodifikation gestern und heute (Berlin: Duncker \& Humblot, 1995); K. Schmidt, Die Zukunft der Kodifikationsidee (Heidelberg: Müller, 1995); C.-W. Canaris, Systemdenken und Systembegriff in der Jurisprudenz entwickelt am Beispiel des deutschen Privatrechts (Berlin: Duncker \& Humblot, 1969); R. Zimmermann, 'Codification: history and present significance of an idea', (1995) 3 European Review of Private Law, 95.

41 Study Group on Social Justice in European Private Law, 'Social Justice in European Contract Law: A Manifesto', (2004) 10 European Law Journal 653; and contributions by B. Lurger and Ch. Joerges in the next issues of this journal. 
interests of those clients willing to choose themselves from a larger range of offers and not to be restricted in this choice by too much mandatory law. It is socially unjust to dismiss without argument the fact that mandatory consumer law has its costs as well ... as it is socially unjust to dismiss the argument that bounded rationality is a fact and that contract law should respond to this fact whenever solutions curing some results of this phenomenon can be named.

The same is true of constitutional values. They are, of course, general principles also of private law and then certainly also of a core instrument such as contracts.

\section{Acquis Communautaire or Comparative Law}

Acquis communautaire and comparative law, the two large trends which formulate their 'European Contract Law', ${ }^{42}$ have quite a bit in common. The former was certainly created taking into account comparative law findings, mostly picking a particularly progressive trend, an approach often described for the Sales Directive which replaced old Roman Law models for about one half of the Member States, among them three of the four big ones, and which approached such modern phenomena as publicity as a core source of information and chains of contracts as the typical form of mass distribution. If then we consider whether a European Contract Code should be based mainly on the acquis communautaire or be developed with considerable independence from it on the basis of comparative law studies, one should phrase the question differently. In the first case, one would use primarily comparative law which has already crystallised in rules which are currently applied and which have passed the political and democratic process. In the second case, comparative law is used freely, ie although it has not yet crystallised in this sense. In the first case, one would take the rules of the acquis communautaire first and also the principles which can be derived from this set of rules and build systematic doctrine on this basis. In other words, there would be a presumption that these rules remain intact unless a clearly superior solution can be shown (for which, purely dogmatic argumentation, without interdisciplinary foundations, would hardly ever suffice). The advantages are evident. The approach named first avoids to a very considerable extent the core problem

42 See on the one hand: H. Kötz, Europäisches Vertragsrecht, Bd. I: Abschluß, Gültigkeit und Inhalt des Vertrages - die Beteiligung Dritter am Vertrag (Tübingen: Mohr-Siebeck, 1996); H. Beale / H. Kötz / A. Hartkamp / D. Tallon, Cases and Materials on Contract Law (Oxford: Hart, 2002); and on the other: the commentaries by Quigley and Grundmann quoted in $\mathrm{n} 20$. 
that private law scholarship lacks democratic legitimacy and will nevertheless play a key role in European codification. Moreover, the adaptation costs are much lower, as the acquis is already practiced. And if one takes the acquis seriously, one will be surprised how many interesting solutions can be found there for modern problems.

The full picture, however, would be that of integration really, with a prevalence accorded to the acquis. It would prevail as far as solutions can be detected in it ... unless a clearly superior solution can be shown (on the basis of contract law tradition and expertise and of institutional economics). On the other hand, it would need to be given a coherent shape. It would need to be supplemented in many respects, but even for this task again, the spirit of the acquis would already serve as a datum. And integration would mean that in the whole task of system building and of finding supplementing rules and institutions, the core three approaches which would always have to be present in the discussion are: the private law tradition and practice developed over centuries; the expertise in modern problems and solutions (information, services and long-term relationships, consumers or more generally regulation, networks etc); and modern methodology, including European Law and social sciences.

One fundamental objection needs to be (re-)addressed briefly. The question is whether the acquis communautaire is not conceived in too instrumentalist a way, in other words, whether it is not too much of a minimum only. ${ }^{43}$ The answer is two-fold. One can argue (as I have done) that already on the substantive law level, the solution found typically strives for an equilibrium between freedom and protection, avoiding both neo-liberal laissez faire and heavy interventionism, and that compromise is typical not only for European, but as well for national political decisions. In fact, often on the European level, progress is possible where it would not be possible on the national level. One can, however, also argue from the perspective of a two level system. A European Code, if subjected to competition, cannot be successful if no overall equilibrium will be found. The developing countries had the power to make the Hague Sales Law of 1964 fail. And in fact, if one adopts the (correct) view that within harmonised areas each enterprise can make an offer on the basis of the minimum level fixed by the directive (more precisely: by its home country law which often reflects exactly this minimum, see n 18 above), Wilhelmsson's argument would be considerably weakened. A European Contract Code based on the (minimum contained in the) acquis communautaire would not alter anything in the status quo.

43 This objection can often be found in a somehow hidden way. Very outspoken (besides Schmid, $n 12$ above): Wilhelmsson, n 26 above. 


\section{A Competitive Process}

The development of a Common Frame of Reference implies considerable input from academia, which in fact is perhaps even the core player. The Directorate General Sanco insisted on having only one network of excellence ... which seems to have excluded trends which deviate from those represented by the Study Group on a European Contract Law and persons which the existing network did not want to invite. Considerable opposition, namely from within those circles which dominated so far the development of the national contract laws (and which have virtually been left out), is to be expected, mainly on the grounds that more in depth discussion is needed. ${ }^{44}$ The argument is not far-fetched that the process has so far excluded the heart of (traditional) contract law expertise. The question is, quite honestly, whether really a European Contract Code cannot be developed in a more open-ended structure and mainly through a competitive process of ideas, giving a chance to all traditional national law sciences and all modern trends and modern approaches to make contributions, at least in principle. The European Contract Code would indeed seem to be an endeavour which is too important to be 'monopolised' by a certain number of scholars at a very early stage and even at the virtually complete exclusion of all circles which so far dominated and developed contract law in all Member States.

44 See already, for instance, B. Dauner-Lieb, 'Auf dem Weg zu einem Europäischen Schuldrecht?', Nene Juristische Wochenschrift 2004, 1431, 1433 et seq. 